\title{
My RNA world: past, present and future
}

\author{
GORDON CARMICHAEL \\ Genetics and Developmental Biology, University of Connecticut Health Center, Farmington, Connecticut 06030-6403, USA
}

Over the past 20 years, we have contributed some (admittedly minor!) insights into RNA processing and function, often using a murine DNA tumor virus as a model system. But some of these small insights have provided important lessons on how to do science, at least to us. I will offer one example. Early on, our focus was on how RNA was expressed and regulated during polyoma virus infection of cultured mouse cells. When we first examined the viral pattern of gene expression from bidirectional transcription units on its circular genome, we saw an excess of early-strand transcripts at early times, but a great excess of late-strand transcripts at late times (after the onset of DNA replication). This could easily have been interpreted as a promoter switch to explain the viral early-late switch, and this was our first thought. However, closer analysis (reporter assays and nuclear run-on experiments) revealed that the early and late promoters appeared to be of roughly equal strength at all times in infection. This led to a revised interpretation that, since the promoters were of equivalent strength, the big difference in the relative accumulation of early-strand and late-strand transcripts at different times in infection must be the result of different turnover rates. Alas, this was also not the case, and understanding the reason taught us a big lesson. One striking thing that changes during the course of polyoma virus infection is the efficiency of transcription termination and polyadenylation of both the early and late transcription units. This results in bidirectional transcription around the genome in both directions. Multi-genomic late-strand transcripts can serve as precursors to late mRNAs, while multi-genomic early strand transcripts cannot be processed into mRNAs. Importantly, since the viral genome is circular and the transcription units are on opposite strands, poly(A) site readthrough allows the abundant formation of dsRNA structures in the nucleus, which can be efficiently and promiscuously edited by the ADAR enzyme such that as many as $50 \%$ of the adenosines are converted to inosines. The bulk of edited late-strand sequences would be degraded, as they lie within introns removed during late mRNA processing. However, many

Corresponding author: carmichael@nso2.uchc.edu

Article and publication date are at http://www.rnajournal.org/cgi/doi/ 10.1261/rna.050161.115. Freely available online through the RNA Open Access option. early-strand mRNAs could retain edited bases. These molecules would be "invisible" in our RNAse protection assays (inosines basepair with cytosines, not uridines), thus explaining why we observed "lower" levels of early-strand RNAs at late times in infection when using our RNAse protection assays. The lesson we learned was that when you don't see an RNA molecule, you can't assume that it isn't being made. Further, even if it is made, you can't assume that it's being degraded. You can really only deduce that you don't see it with the methods you are using. In our case, early-strand molecules were abundant at late times, but not seen because they were so heavily modified that they escaped detection by our assays. We learned how easy it is to overinterpret data that appears straightforward.

This work prompted us to further our studies on the function and fate of nuclear dsRNAs, and have led us in a number of interesting and unexpected research directions, including into embryonic stem cell biology and long noncoding RNAs. Many of our recent papers have been on these subjects, but all have their roots in polyoma virus biology.

Where do I see the future of RNA research and the most likely areas for new conceptual discoveries? From my personal perspective, I see a number of areas that are poised for progress. Of course, technological improvements will continue to drive many discoveries, which would otherwise not be possible. Here are the areas I think have the most potential for exciting new advances:

1. The "dark matter" of the genome will include a number of new surprises. We still have not fully examined the very large amount of transcribed but noncoding RNA from the genome. For example, transcribed repetitive elements may have functions in gene regulation or nuclear architecture that have been unappreciated. There may still exist multiple "unconventional" modes of RNA processing. We have recently seen a resurgence of interest in circular RNAs of various forms, but other types of processing may await discovery.

2. Roles of RNA modifications. Many modifications to RNA have been described, but we still don't know what many of

(C) 2015 Carmichael This article, published in $R N A$, is available under a Creative Commons License (Attribution-NonCommercial 4.0 International), as described at http://creativecommons.org/licenses/by-nc/4.0/. 
them do. Also, we still don't know how widespread some of them are.

3. Noncoding RNAs. Although there is great current interest in this area, there is still much to learn about the role of RNA in gene regulation and nuclear structure.

4. Local effects of RNAs. An lncRNA in the nucleus may have functions different from the same lncRNA in the cytoplasm. Also, different RNAs may have different functions in different cells.
5. The role of dynamic RNA folding or shape changes in cellular effects.

6. Finally, I think that we must be mindful to weed out the noise. Just because RNAs are in cells, this doesn't mean that they are doing anything important there. There may be critical dosage effects as well as cell-to-cell variability. I worry that undue attention may be paid to molecules that exist in only several copies per cell, or to molecules that are produced as byproducts of other processes but are lacking functions. 

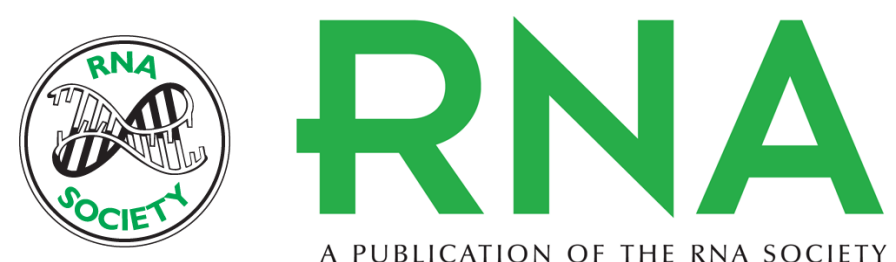

A PUBLICATION OF THE RNA SOCIETY

\title{
My RNA world: past, present and future
}

\author{
Gordon Carmichael
}

RNA 2015 21: 578-579
Open Access Freely available online through the RNA Open Access option.
Creative This article, published in $R N A$, is available under a Creative Commons License Commons (Attribution-NonCommercial 4.0 International), as described at License http://creativecommons.org/licenses/by-nc/4.0/. Email Alerting $\begin{aligned} & \text { Receive free email alerts when new articles cite this article - sign up in the box at the } \\ & \text { Service }\end{aligned}$ top right corner of the article or click here.

To subscribe to $R N A$ go to:

http://rnajournal.cshlp.org/subscriptions

(C) 2015 Carmichael; Published by Cold Spring Harbor Laboratory Press for the RNA Society 